\title{
The nutritive value of five pasture species occurring in the summer grazing ranges of the Pyrenees
}

\author{
A. Marinas ${ }^{1}$, R. García-González ${ }^{1}$ and M. Fondevila² ${ }^{2}$ \\ ${ }^{1}$ Instituto Pirenaico de Ecología, CSIC, Apartado 64, 22700 Jaca, Huesca, Spain \\ ${ }^{2}$ Departamento de Producción Animal y Ciencia de los Alimentos, Universidad de Zaragoza, Miguel Servet 177, 50013 \\ Zaragoza, Spain \\ † Corresponding author. E-mail : mfonde@posta.unizar.es
}

\begin{abstract}
Five species of alpine pasture plants from the Pyrenees representing 3 botanical groups : grasses (Festuca eskia, Nardus stricta), forbs (Anthyllis vulneraria, Galium verum) and shrubs (Echinospartum horridum), were collected monthly from June to September and analysed for nitrogen $(N)$ content, cell wall composition, in vitro enzymatic digestibility (DMDe) and volume of gas produced by microbial fermentation. Among the dicotyledenous varieties, A. vulneraria and G. verum showed the highest nutritive value whilst that of E. horridum was low due to high lignin content. Grasses showed moderate nutritive values in June rapidly decreasing thereafter. Nitrogen content and organic matter digestibility $(O M D g)$ of A. vulneraria remained relatively constant through the sampling period whereas it abruptly decreased for remaining species from July. Gas production significantly differed among species during the first $48 \mathrm{~h}$ of microbial fermentation but not at later stages of fermentation. Collection date did not affect gas production before $24 \mathrm{~h}$ of incubation but significant differences were found thereafter with samples from June and July being more degraded than from August and September. Principal component analysis associated $O M D g$ positively with $N$ content and gas production and negatively with fibre content. Lignin proportion did not significantly correlate with gas production or with $O M D g$, suggesting that the degree of lignification is not the only factor affecting microbial fermentation but other factors such as lignin tissue locations may be involved. A. vulneraria has been revealed as very good forage with a high potential in extensive animal production systems. Both OMDg and DMDe methods seem more accurate than chemical analyses for evaluating forages at different stages of maturity.
\end{abstract}

Keywords: Alpine grasslands, digestibility, gas production.

\section{Introduction}

As in other mountain systems, in the Pyrenees there is an alpine (high altitude) pasture band, generally over $1800 \mathrm{~m}$, that is utilized for livestock grazing. These pastures are spread over $10000 \mathrm{~km}^{2}$ and are an important source of forage for both wild and domestic ruminants. Traditionally, ruminant production in the area is based on grazing alpine pastures only during the summer, whereas from autumn to spring herds are moved down to the valleys, and offered other forage resources (Montserrat and Fillat, 1990). Gómez et al. (1997) highlighted the high diversity of Pyrenean high altitude pastures which are composed of more than 500 species. The major proportion of the biomass is composed of grasses (50 to 60\%), such as Festuca rubra, F. eskia, F. gautieri, Nardus stricta, whilst legumes such as Trifolium alpinum, Anthyllis vulneraria, Lotus alpinus and forbs such as Plantago spp. comprised the remainder of the pasture (approx. 10 to $20 \%$ legumes and 5 to $10 \%$ forbs).

However, despite the importance of alpine pastures in the livestock system in the Pyrenees, there is a lack of information about the nutritional value of the different species. The botanical group of the species and their phenology are two of the main factors influencing nutritive value. Digestibility of shrubs and grasses are generally lower than legumes and other herbaceous dicotyledenous species. In 
addition, the quality of immature growth stages is generally higher than mature stages (Van Soest, 1994). Negative effect of age on the nutritive value of forages is mainly due to a low ratio of leaves to stem (Ugherughe, 1986) and an increase in stem cell walls and lignification.

This work investigates the effect of plant age on the nutritive value of five pasture species commonly found in Pyrenean pastures and representatives of different botanical groups, selected on the basis of their consumption by the ruminant livestock. In addition, we compare three different methods to estimate the nutritional value of these forages.

\section{Material and methods}

The study area consists of a 1200 ha grazing area located in the Western Spanish Pyrenees (Aisa Valley) at an altitude of between 1600 and $2200 \mathrm{~m}$. Pastures were subjected to a moderate grazing pressure of 0.5 to $0.8 \mathrm{LU}$ per ha (1 livestock unit (LU) corresponds to a 500-kg cow) during summer. Local climate is characterized by cold winters and temperate summers and annual rainfall is between 1500 and $2000 \mathrm{~mm}$. Total rainfall during the sampling period was $262.7 \mathrm{~mm}$, and maximum and minimum temperatures ranged between 7.6 and $22 \cdot 1^{\circ} \mathrm{C}$, with an average temperature of $14 \cdot 8^{\circ} \mathrm{C}$. Environmental and animal management characteristics of the studied area are detailed in García-González et al. (1990 and 1991).

Plant species were selected on the basis of their abundance in the study area (Gómez et al., 1997). They are also representatives of different botanical groups (grasses, forbs, and shrubs) which correspond to different forage characteristics (Van Soest, 1994). Festuca eskia and Nardus stricta (grasses) form the major proportion of two of the main phytosociological communities in the Pyrenees : Festucion eskiae and Nardion strictae (BraunBlanquet, 1948). Anthyllis vulneraria (legume) and

Table 1 Description of the stage of plant development of the different species when collected on each date

\begin{tabular}{lcccc}
\hline \hline Species & June & July & August & September \\
\hline Festuca eskia & 1 & 3 & 5 & 7 \\
Nardus stricta & $1-2$ & 5 & 7 & 8 \\
Anthyllis vulneraria & $3-4$ & 5 & 6 & 7 \\
Galium verum & $1-2$ & 3 & $3-4$ & $8-9$ \\
Echinospartum horridum & 1 & 3 & 7 & $6-9$ \\
\hline \hline
\end{tabular}

1: vegetative growth; 2 : budding; 3 : flowering; 4 : beginning of fruiting, seeding; 5: fruiting, seeding; 6: dispersing seed, fruit; 7: some leaves dried; 8: senescence; 9: regrowth.
Galium verum (herbaceous dicotyledenous species) are characteristic of Festucion gautieri and Bromion erecti communities, that are important in the area in terms of surface and herbivore utilization (GarcíaGonzález et al., 1991). Echinospartum horridum (a spiny cushion shrub) is an invasive species in Western Pyrenees that has been favoured by pastoral fire and stocking rate diminution, and it is also heavily consumed by browsing ruminants during growing and flowering periods (Aldezábal, 2001). Sampling criteria was that samples would reflect the nutritive conditions of the species as they were found by the grazing herbivores in the study area.

A non-fenced parcel of roughly 1 ha per species, representing average environmental and herbivore utilization conditions, were marked and each species was sampled at monthly intervals from June to September 2000. Except for E. horridum, the selected species are difficult to sample in purity because they are frequently mixed with that of other species, and so the leaves and stems of each species were selected and cut by hand. Each sample was composed of different individuals of the same species up to $50 \mathrm{~g}$ fresh weight. Samples were taken from ungrazed items, and were clipped simulating the feeding height of herbivores : upper half of unfertile leaves (tiller) for grasses, total stem with their leaves (ca. $10 \mathrm{~cm}$ high) for forbs and current annual growth (ca. $5 \mathrm{~cm}$ ) for the shrub. A description of the phenology for each sample is shown in Table 1. Samples were thoroughly mixed in the laboratory, dried at $60^{\circ} \mathrm{C}$ for $48 \mathrm{~h}$, and ground to a maximum $1 \mathrm{~mm}$ particle size.

The microbial fermentation pattern of collected species was studied by measuring the gas produced during the in vitro incubation of samples, following the technique of Theodorou et al. (1994). Two fermentation trials were conducted, with duplicate sealed bottles with approximately $800 \mathrm{mg}$ of each substrate in each trial. In addition, triplicate bottles of incubation solution but without substrate were also included as blanks. Rumen contents were obtained from three adult sheep via rumen cannula just before the morning food was given $(900 \mathrm{~g}$ of a $50: 50$ barley straw and lucerne hay diet enriched with $20 \mathrm{~g}$ of a vitamin-mineral mixture), pooled and used as the main portion of the inoculum solution at a final proportion of $0 \cdot 10$ of the total inoculum volume. Bottles were filled $(80 \mathrm{ml})$ and incubated at $39^{\circ} \mathrm{C}$, and the pressure of gas produced in each bottle was recorded by means of a HD8804 manometer with a TP 804 pressure gauge (DELTA OHM) after 2, $4,6,8,12,24,36,48,60,72$ and 96 h of incubation. Readings were converted into volume $(\mathrm{ml})$ by using the following pre-established linear regression 
between pressure recorded (mbar) in the same type of bottles and known air volumes:

$$
\begin{gathered}
\text { volume }=(\text { pressure }-0.981) / 30.375 \\
(r=0.996 ; \text { no. }=64) .
\end{gathered}
$$

The gas volume for each incubation time was expressed per unit of incubated dry matter (DM). Apparent organic matter (OM) digestibility (OMDg, $\%)$ of forages was estimated from the volume of gas produced after $24 \mathrm{~h}$ of incubation (GP, ml/200 mg $\mathrm{DM})$ and the proportion of crude protein $(\mathrm{CP}, \mathrm{g} / \mathrm{kg}$ $\mathrm{DM}$ ), following the equation of Menke and Steingass (1988):

$$
\begin{gathered}
\mathrm{OMDg}=24 \cdot 91+0 \cdot 7222 \mathrm{GP}+0 \cdot 0815 \mathrm{CP} ; \\
\text { no. }=185 ; R^{2}=0 \cdot 78 .
\end{gathered}
$$

To estimate the pattern of microbial fermentation, the average cumulative gas production from each forage species and from each sampling date was fitted iteratively to the model proposed by France et al. (1993):

$$
y=A\{1-\exp [-b(t-T)-c(\sqrt{ } t-\sqrt{ } T)]\},
$$

where $y$ represents the cumulative gas production $(\mathrm{ml}), t$ is incubation time (h), $A$ is asymptote (total gas; $\mathrm{ml}), T$ is lag time (h) and $b$ and $c$ are rate constants (per $h$ and per $h^{1 / 2}$ ). The maximum proportion of error allowed in the adjustment was fixed at 0.001 . The time required to reach one half of the maximum gas production $\left(t_{1 / 2}\right)$ was also estimated, and the fractional degradation rate $(\mu$, per h) was calculated at that point (giving $\mu_{1 / 2}$ ) according to:

$$
\mu_{1 / 2}=b+c /\left(2 \sqrt{ } t_{1 / 2}\right)
$$

In vitro enzymatic digestion (DMDe) was determined following Aufrère and Michalet-Doreau (1988), incubating duplicated samples in two consecutive 24-h phases, firstly with pig stomach pepsin (FLUKA, ref. 77160) and secondly with cellulases from Trichoderma viridae (BDH, ref. 39074) at a $\mathrm{pH} 4.6$. Dried plant samples were analysed for their Kjeldahl nitrogen by the Association of Official Analytical Chemists (1990) methods. Neutral-detergent fibre (NDF), acid-detergent fibre (ADF), acid-detergent lignin (ADL) and residual ashes were determined sequentially by the procedures described by Van Soest et al. (1991). All analyses were performed in duplicate, and the average values were used for comparing samples. An estimation of DM digestibility (DMDc) of samples was calculated from the chemical composition data, using the equation proposed by Van Soest (1994), considering the cellular content (CC) digestibility to be : $(0.98 \mathrm{CC})$ 12.9 and the NDF digestibility to be : NDF [1.473 $\left.0.789 \log _{10}(\mathrm{ADL} / \mathrm{ADF} \times 100)\right]$.

Differences among experimental treatments were contrasted by analysis of variance as a $5 \times 4$ factorial design, comparing the effect of species, the cutting date and their interaction with the residual. In the in vitro gas production studies, the average value of the two bottles from each incubation run was considered to be the experimental unit, and the experimental run was considered as a block. Treatment means were compared by the post hoc Tukey's $t$ test at a $P<0.05$ and orthogonal contrasts were performed. A principal components analysis (PCA) with chemical composition, digestibility and gas production variables was performed. The PCA analysis allows the detection of the degree of association between variables by means of their relative position in a multivariate space, which is reduced to orthogonal directions (axis) of maximum variance in the original data (Afifi and Clark, 1996). In addition, a projection of cases (species-collection-date data) over the same PCA axis was conducted to establish the

\begin{tabular}{|c|c|c|c|c|c|}
\hline Species & Date & $\mathrm{N}$ & NDF & $\mathrm{ADF}$ & ADL \\
\hline F. eskia & \multirow[t]{5}{*}{ June } & $27 \cdot 8$ & 681 & 306 & 57 \\
\hline N. stricta & & $28 \cdot 4$ & 749 & 300 & 51 \\
\hline A. vulneraria & & $22 \cdot 3$ & 454 & 274 & 75 \\
\hline G. verum & & $33 \cdot 8$ & 316 & 194 & 82 \\
\hline E. horridum & & $24 \cdot 8$ & 571 & 354 & 165 \\
\hline F. eskia & \multirow[t]{5}{*}{ July } & $14 \cdot 2$ & 733 & 367 & 56 \\
\hline N. stricta & & $19 \cdot 2$ & 768 & 368 & 77 \\
\hline A. vulneraria & & $22 \cdot 2$ & 362 & 222 & 65 \\
\hline G. verum & & $22 \cdot 8$ & 380 & 230 & 107 \\
\hline E. horridum & & $14 \cdot 0$ & 633 & 456 & 189 \\
\hline F. eskia & \multirow[t]{5}{*}{ August } & $11 \cdot 5$ & 640 & 316 & 53 \\
\hline N. stricta & & $13 \cdot 8$ & 770 & 359 & 44 \\
\hline A. vulneraria & & $21 \cdot 7$ & 356 & 158 & 52 \\
\hline G. verum & & $22 \cdot 9$ & 376 & 233 & 121 \\
\hline E. horridum & & $11 \cdot 8$ & 677 & 515 & 215 \\
\hline F. eskia & \multirow[t]{9}{*}{ September } & $10 \cdot 9$ & 674 & 479 & 60 \\
\hline N. stricta & & $10 \cdot 0$ & 777 & 360 & 39 \\
\hline A. vulneraria & & $20 \cdot 9$ & 293 & 237 & 40 \\
\hline G. verum & & $20 \cdot 1$ & 377 & 230 & 103 \\
\hline E. horridum & & $12 \cdot 3$ & 698 & 490 & 204 \\
\hline Residual s. d. & & $3 \cdot 26$ & 49.4 & $50 \cdot 8$ & $16 \cdot 3$ \\
\hline \multicolumn{5}{|l|}{ Significance of: } & \\
\hline species effect & & $* *$ & $* * *$ & $* * *$ & $* * *$ \\
\hline date effect & & $* * *$ & & & \\
\hline
\end{tabular}
relationships between cases and variables observing their relative position in the factor space (StatSoft, 1995).

Table 2 Chemical compositiont $(\mathrm{g} / \mathrm{kg}$ dry matter) of plants according to the collection date

$+\mathrm{N}=$ nitrogen; $\mathrm{NDF}=$ neutral-detergent fibre; $\mathrm{ADF}=$ aciddetergent fibre; ADL = acid-detergent lignin. 


\section{Results}

Chemical composition of the five studied species at each sampling date is shown in Table 2. There were significant differences among species for all variables. The nitrogen $(\mathrm{N})$ content of $G$. verum was higher than F. eskia and E. horridum $(P<0 \cdot 01)$. A. vulneraria and $G$. verum had the lowest values of NDF and $\operatorname{ADF}(P<0.001)$, whereas E. horridum and $G$. verum showed the highest lignin content $(P<0.001)$. Only $\mathrm{N}$ concentration varied with time $(P<0.001)$, decreasing from June $(27.4 \mathrm{~g} / \mathrm{kg})$ to other sampling dates $(18.4,16.3$ and $14.8 \mathrm{~g} / \mathrm{kg}$ in July, August and September, respectively). All the species showed this trend, except $A$. vulneraria, whose $\mathrm{N}$ content remained fairly constant through the whole experimental period.

When the volume of gas produced from each species on each date by their microbial fermentation in vitro was studied, no significant differences for the interaction species $X$ date were observed at any incubation time. Therefore, the average means of the gas production pattern for each species and each collection date are presented in Figures 1 and 2, respectively. Differences in the volume of gas produced by microbial fermentation were observed among the studied species during the first $48 \mathrm{~h}$ of incubation $(P<0.01)$ but not thereafter. During the first $8 \mathrm{~h}$ of incubation, A. vulneraria showed higher gas volumes than the other species, and differences from F. eskia, and with E. horridum and N. stricta were maintained during the first 36 and $48 \mathrm{~h}$ of incubation, respectively. The gas volume produced from $G$. verum was higher than from $N$. stricta at 6 to $36 \mathrm{~h}$, and higher than E. horridum at 12 and $24 \mathrm{~h}$. The parameters of the curves fitted to the average gas production pattern for each species are shown in

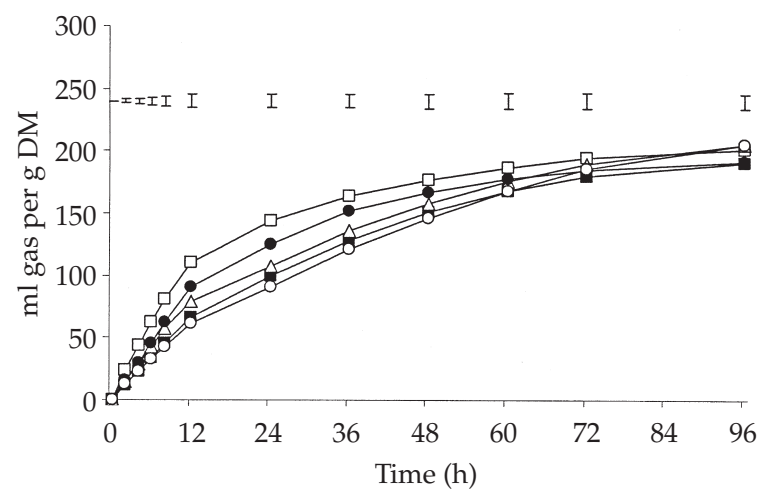

Figure 1 Average gas production pattern from samples taken from different species (F. eskia, $\triangle ; N$. stricta, $\bigcirc$; A. vulneraria, $\square$; G. verum, $\mathbf{0}$; E. horridum, $\mathbf{\square}$ ) when incubated in vitro, expressed per unit of incubated dry matter (no. $=8$ ). Upper bars show standard error of means.

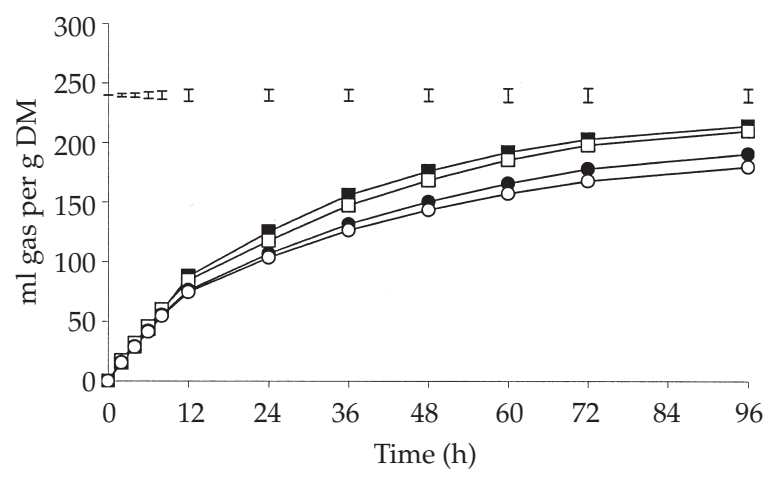

Figure 2 Average gas production pattern from samples taken from different sampling dates (June, $\mathbf{\square}$; July, $\square$; August, - September, O) when incubated in vitro, expressed per unit of incubated dry matter (no. $=10$ ). Upper bars show standard error of means.

Table 3. Although the fitted parameters were not compared statistically, it can be seen that the maximum gas production $(A)$ from $N$. stricta and $F$. eskia was higher than from the other species. This is in apparent contradiction with the recorded gas volumes at $96 \mathrm{~h}$ of incubation, which showed smaller differences (Table 3). This can be explained by the lower fractional fermentation rate of the former species, allowing the asymptote to be reached only after the recorded incubation period had finished, thus forcing the fitted curve to a higher maximum. A. vulneraria and $G$. verum were fermented faster than the other species, as shown by their fractional rates of fermentation $\left(\mu_{1 / 2}\right)$, and reached half of their potential gas production in 12 and $15 \mathrm{~h}$, respectively, in agreement with the pattern shown in Figure 1. In all cases, lag time was lower than $1 \mathrm{~h}$.

As can be seen from Figure 2, no differences among collection dates were observed until $24 \mathrm{~h}$ of fermentation, when samples from June produced more gas than those from September $(P<0 \cdot 05)$. From $36 \mathrm{~h}$ onwards, the stage of maturity of species linearly affected their microbial fermentation $(P<0.05)$, the gas volume of samples from June being higher than August and September, and those from July higher than September. In this case, the estimated maximum gas production ( $A$; Table 3 ) was slightly higher than the observed results after $96 \mathrm{~h}$ of incubation, but there was a linear reduction of the fractional rate of fermentation as the stage of maturity advanced.

Estimates of digestibility from chemical composition, in vitro enzymatic digestion and gas production for species and collection dates are presented in Table 4 . There were significant differences in digestibility 
Table 3 Coefficients of the curves fitted to the average gas production pattern of each species and on each sampling date, together with the volume of gas recorded after $96 \mathrm{~h}$ of incubation (residual s. $d .=17.6 ; \mathrm{ml} / \mathrm{g}$ dry matter $(D M))+$

\begin{tabular}{|c|c|c|c|c|c|c|c|}
\hline & $A$ & $b$ & $c$ & $T$ & $t_{1 / 2}$ & $\mu_{1 / 2}$ & Vol. $96 \mathrm{~h}$ \\
\hline F. eskia & $\begin{array}{c}231 \\
(11 \cdot 8)\end{array}$ & $\begin{array}{c}0.018 \\
(0.0039)\end{array}$ & $\begin{array}{c}0.046 \\
(0.0129)\end{array}$ & $\begin{array}{c}0.05 \\
(0 \cdot 119)\end{array}$ & $26 \cdot 2$ & $0 \cdot 022$ & 205 \\
\hline N. stricta & $\begin{array}{c}263 \\
(12 \cdot 7)\end{array}$ & $\begin{array}{c}0.014 \\
(0.0020)\end{array}$ & $\begin{array}{c}0.021 \\
(0.0065)\end{array}$ & $\begin{array}{c}0.01 \\
(0.075)\end{array}$ & 39.9 & $0 \cdot 016$ & 206 \\
\hline A. vulneraria & $\begin{array}{c}198 \\
(4 \cdot 3)\end{array}$ & $\begin{array}{c}0.044 \\
(0.0081)\end{array}$ & $\begin{array}{c}0.056 \\
(0.0267)\end{array}$ & $\begin{array}{c}0.04 \\
(0 \cdot 117)\end{array}$ & $11 \cdot 6$ & $0 \cdot 052$ & 201 \\
\hline G. verum & $\begin{array}{c}192 \\
(3 \cdot 7)\end{array}$ & $\begin{array}{c}0.042 \\
(0.0053)\end{array}$ & $\begin{array}{c}0.017 \\
(0.0190)\end{array}$ & $\begin{array}{c}0 \cdot 10 \\
(0.233)\end{array}$ & $15 \cdot 1$ & $0 \cdot 044$ & 192 \\
\hline E. horridum & $\begin{array}{c}208 \\
(5 \cdot 0)\end{array}$ & $\begin{array}{c}0.025 \\
(0.0025)\end{array}$ & $\begin{array}{c}0.015 \\
(0.0095)\end{array}$ & $\begin{array}{c}0.05 \\
(0 \cdot 170)\end{array}$ & $25 \cdot 0$ & 0.026 & 191 \\
\hline June & $\begin{array}{c}222 \\
(5 \cdot 6)\end{array}$ & $\begin{array}{c}0.031 \\
(0.0041)\end{array}$ & $\begin{array}{c}0.023 \\
(0.0152)\end{array}$ & $\begin{array}{c}0.09 \\
(0.208)\end{array}$ & $15 \cdot 6$ & 0.042 & 214 \\
\hline July & $\begin{array}{c}226 \\
(7 \cdot 5)\end{array}$ & $\begin{array}{c}0.023 \\
(0.0037)\end{array}$ & $\begin{array}{c}0.042 \\
(0.0131)\end{array}$ & $\begin{array}{c}0.04 \\
(0 \cdot 109)\end{array}$ & $21 \cdot 8$ & $0 \cdot 028$ & 210 \\
\hline August & $\begin{array}{c}208 \\
(8 \cdot 0)\end{array}$ & $\begin{array}{c}0.021 \\
(0.0038)\end{array}$ & $\begin{array}{c}0.050 \\
(0.0131)\end{array}$ & $\begin{array}{c}0.04 \\
(0 \cdot 101)\end{array}$ & $22 \cdot 6$ & $0 \cdot 026$ & 191 \\
\hline September & $\begin{array}{c}192 \\
(7 \cdot 2)\end{array}$ & $\begin{array}{c}0.022 \\
(0.0042)\end{array}$ & $\begin{array}{c}0.053 \\
(0.0145)\end{array}$ & $\begin{array}{c}0.05 \\
(0.104)\end{array}$ & $20 \cdot 9$ & $0 \cdot 028$ & 180 \\
\hline
\end{tabular}

† In brackets are standard errors of means for curve coefficients. $A$ : total gas as the asymptote (ml/g DM); $b, c:$ rate constants (per $\mathrm{h}$ and per $\mathrm{h}^{1 / 2}$ ); $T$ : lag time (h); $t_{1 / 2}$ and $\mu_{1 / 2}$ : time $(\mathrm{h})$ required to reach 0.50 total gas production and fractional degradation rate (per $\mathrm{h})$ at that time.

among species regardless of the method used. However, E. horridum recorded the lowest digestibility when calculated from chemical composition $(P<0.05)$, but when this parameter was estimated from in vitro enzymatic digestion or gas production, it was no different to N. stricta or F. eskia. $A$. vulneraria and $G$. verum showed higher digestibility values than the other species $(P<0.001)$. Differences among collection dates in digestibility

Table 4 Estimates of digestibility ( $\mathrm{g} / \mathrm{kg}$ dry matter) from chemical composition $(D M D c)$, in vitro enzymatic digestion (DMDe) and gas production $(\mathrm{OMD} g)$ for each species and each collection date

\begin{tabular}{lccc}
\hline \hline & DMDc & DMDe & OMDg \\
\hline F. eskia & $545^{\mathrm{a}}$ & $541^{\mathrm{b}}$ & $487^{\mathrm{b}}$ \\
N. stricta & $524^{\mathrm{a}}$ & $462^{\mathrm{b}}$ & $472^{\mathrm{b}}$ \\
A. vulneraria & $620^{\mathrm{a}}$ & $727^{\mathrm{a}}$ & $568^{\mathrm{a}}$ \\
G. verum & $554^{\mathrm{a}}$ & $687^{\mathrm{a}}$ & $544^{\mathrm{a}}$ \\
E. horridum & $340^{\mathrm{b}}$ & $428^{\mathrm{b}}$ & $473^{\mathrm{b}}$ \\
June & 508 & 566 & $570^{\mathrm{a}}$ \\
July & 493 & 517 & $513^{\mathrm{b}}$ \\
August & 513 & 596 & $487^{\mathrm{bc}}$ \\
September & 552 & 596 & $465^{\mathrm{c}}$ \\
Residual s. d. & $51 \cdot 9$ & $55 \cdot 5$ & $23 \cdot 5$ \\
Significance of: & & & $* * *$ \\
$\quad$ species effect & $* * *$ & & $* *$ \\
date effect & & & \\
\hline
\end{tabular}

$\overline{a, b, c}$ When comparing either species or dates of sampling, different superscripts indicate significant differences $(P<0 \cdot 05)$. were only detected with estimates from gas production, being highest in June, and higher in July than in September $(P<0.001)$.

The possible relationship between the different parameters studied was evaluated by a principal component analysis (Figure 3). Factor I explained 0.66 of total variance, and represents a gradient of quality, since parameters of cell wall composition, that are generally inversely related to forage quality

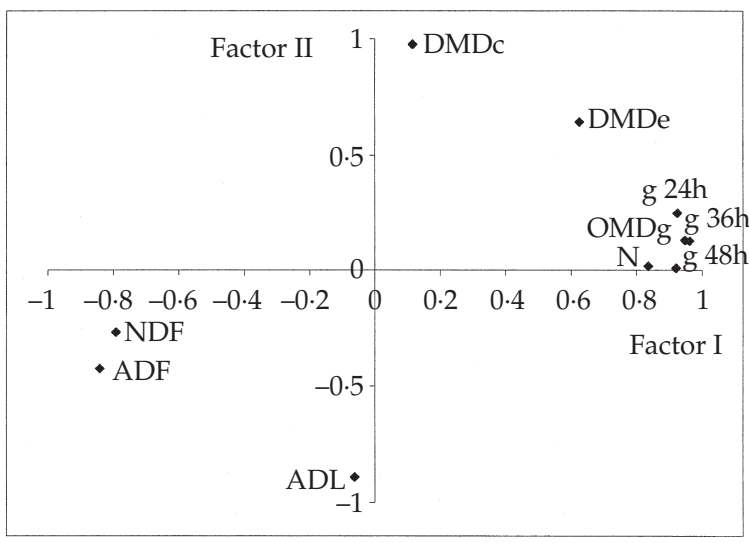

Figure 3 Distribution of the different parameters used to compare the nutritive value according to factor I and II of the principal component analysis. 


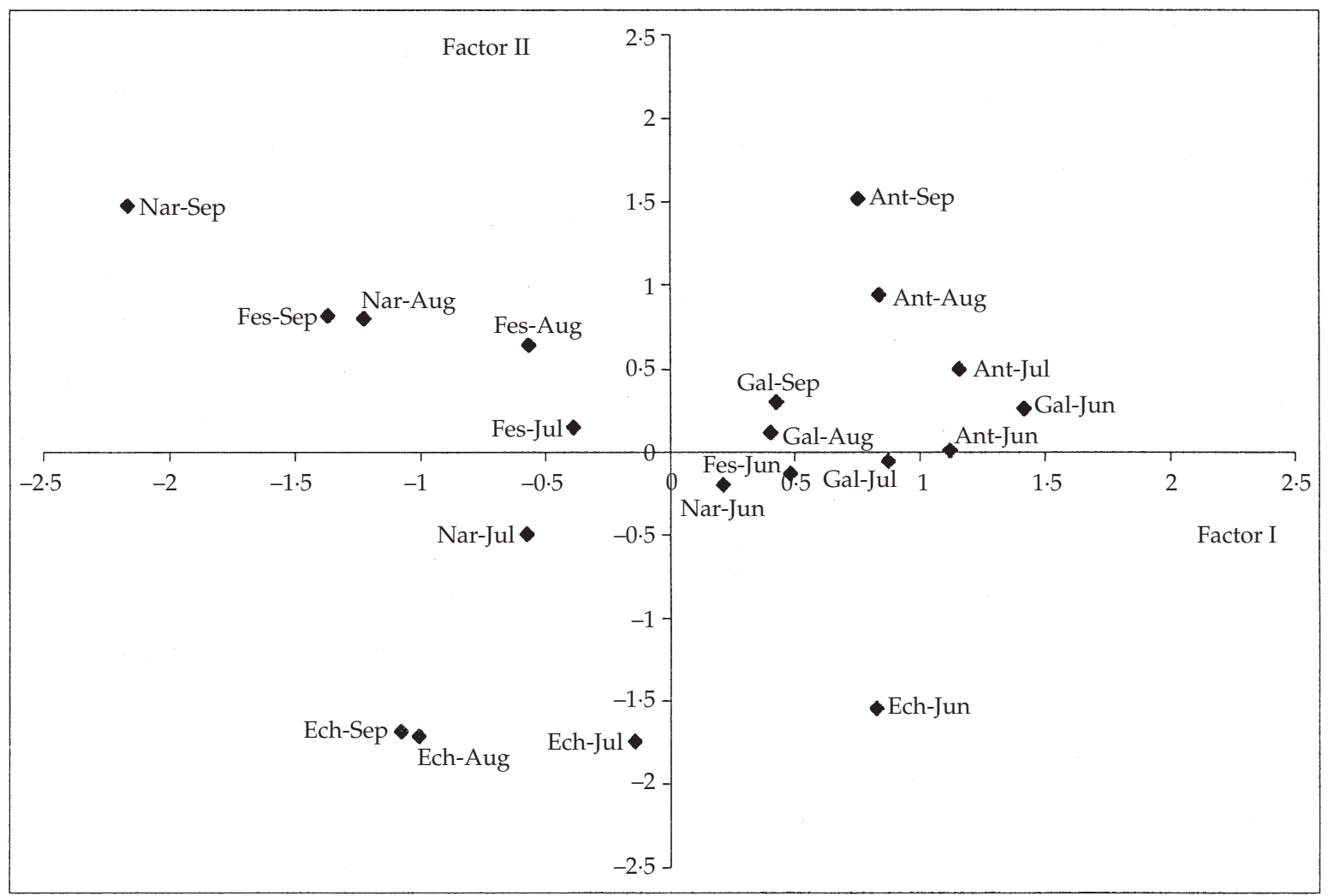

Figure 4 Distribution of the five forage species studied at different collection dates according to factor I and II of the principal component analysis.

Table 5 Correlation coefficients between the volume of gas produced at 12,24 and 48 h of incubation and other studied variables (no. = 20)

\begin{tabular}{|c|c|c|c|c|c|c|c|c|c|}
\hline & $24 \mathrm{~h}$ & $48 \mathrm{~h}$ & NDF & ADF & ADL & $\mathrm{N}$ & DMDc & DMDe & OMDg \\
\hline $12 \mathrm{~h}$ & $\begin{array}{c}0.98 \\
* * *\end{array}$ & $\begin{array}{c}0 \cdot 82 \\
* * *\end{array}$ & $\underset{* * *}{-0 \cdot 81}$ & $\begin{array}{c}-0.71 \\
* * *\end{array}$ & $-0 \cdot 36$ & 0.43 & $\begin{array}{l}0.60 \\
* *\end{array}$ & $\begin{array}{c}0.80 \\
* * *\end{array}$ & $\underset{* * *}{0.82}$ \\
\hline $24 \mathrm{~h}$ & & $\begin{array}{c}0.91 \\
* * *\end{array}$ & $\underset{* * *}{-0.83}$ & $\underset{* * *}{-0.75}$ & -0.32 & $\begin{array}{l}0.55 \\
* *\end{array}$ & $\begin{array}{l}0.56 \\
* *\end{array}$ & $\begin{array}{c}0.78 \\
* * *\end{array}$ & $\underset{* * *}{0 \cdot 88}$ \\
\hline $48 \mathrm{~h}$ & & & $\underset{* * *}{-0.74}$ & $\underset{* * *}{-0.75}$ & -0.22 & $\underbrace{0.74}_{* * *}$ & $0 \cdot 37$ & $\underset{* *}{0.63}$ & $\underset{* * *}{0.87}$ \\
\hline NDF & & & & $\begin{array}{l}0.75 \\
* * *\end{array}$ & 0.05 & $\begin{array}{c}-0.53 \\
*\end{array}$ & $\begin{array}{c}-0 \cdot 45 \\
*\end{array}$ & $\begin{array}{c}-0.88 \\
* * *\end{array}$ & $-\underset{* * *}{-0.70}$ \\
\hline $\mathrm{ADF}$ & & & & & $\begin{array}{c}0.53 \\
*\end{array}$ & -0.69 & $\underset{* * *}{-0 \cdot 67}$ & $\underset{* * *}{-0.83}$ & $\underset{* * *}{-0.76}$ \\
\hline ADL & & & & & & $-0 \cdot 17$ & $\begin{array}{c}-0 \cdot 87 \\
* * *\end{array}$ & $-0 \cdot 43$ & $-0 \cdot 24$ \\
\hline $\mathrm{N}$ & & & & & & & $0 \cdot 22$ & $\begin{array}{c}0.44 \\
*\end{array}$ & $\begin{array}{l}0.91 \\
* * *\end{array}$ \\
\hline DMDc & & & & & & & & $\begin{array}{c}0.76 \\
* * *\end{array}$ & 0.37 \\
\hline DMDe & & & & & & & & & $\begin{array}{c}0 \cdot 61 \\
* * \\
\end{array}$ \\
\hline
\end{tabular}


appeared in the negative part of this axis whereas nitrogen content, gas production parameters and OMDg are placed in the positive part of the axis. The negative extreme of factor II was related to the lignin content, and the chemical digestibility estimation appeared in the positive part of the axis, whereas the enzymatic digestibility was related to both OMDg and gas production results. Together, both factors I and II explained 0.85 of total variance. Figure 4 shows a projection of species-collection-date cases of the early PCA axis. Samples of A. vulneraria (Ant) and $G$. verum (Gal) at all dates were located in the positive rank of factor I, indicating higher gas production and lower cell walls and lignin proportions, slightly higher in the June-July than in the August-September periods. June samples of $E$. horridum, (Ech), F. eskia (Fes) and N. stricta (Nar) also appear in the positive part of factor I, the former with a low factor II coefficient because of its high lignin proportion. For the grasses, it seems that their quality is more affected by their cell wall proportion than by microbial fermentation because they appear in the negative part of factor I.

Correlation coefficients among the studied parameters are shown in Table 5. Significant positive correlations have been observed between the volume of gas produced at 12,24 or $48 \mathrm{~h}$ and OMDg, $\mathrm{N}$ content and enzymatic digestibility. These variables are also negatively correlated with NDF and ADF proportions, in agreement with the principal component analysis. However, the correlation coefficient between gas production and $\mathrm{N}$ content increased with the time of incubation, being higher at 48 than $24 \mathrm{~h}$, and not significant at $12 \mathrm{~h}$ of fermentation.

\section{Discussion}

Both the volume of gas produced after $24 \mathrm{~h}$ of incubation (Menke and Steingass, 1988) and the parameters of the fitted curve (Khazaal et al., 1995) have been used successfully to predict the apparent digestibility of forage foods, showing better results than other approximations using enzyme digestion or chemical composition (Aiple et al., 1996; Minson, 1998). However, since fermentation of crude protein is inversely related to gas production, (Menke and Steingass, 1988; González Ronquillo et al., 1998), it is necessary to consider the $\mathrm{N}$ content of foods for a better fit, as has been used to calculate average OMDg results in Table 4.

Digestibility estimates from the different methods were different $(P<0.01)$ with DMDe showing the highest values. Mean values of estimates from gas production compared with those from chemical composition did not differ significantly but values from the two methods were not correlated, as they were with enzymatic and gas production estimates (Table 5). The position of DMDe, OMDg and DMDc in the PCA analysis indicates that the latter is the poorer estimator of digestibility compared with the others. In addition, digestibility estimation from gas production showed a lower coefficient of variation than both DMDc and DMDe (0.05, 0.10 and 0.10, respectively). The distance of DMDc from the rest of the quality factors in Figure 3 can be explained by the influence of lignin proportion in this digestibility estimator (Van Soest, 1994). In vitro enzymatic digestibility is a useful method for treatment comparison, although its results differ from in vivo apparent digestibility (Weiss, 1995). The fact that the equation used for OMDg estimation (Menke and Steingass, 1988) was established with volume readings in glass syringes, whereas in this study a pressure system was used, must be considered. However, we lack equations for estimating digestibility from gas pressure systems but the differences in our estimates were of sufficient magnitude as to probably not affect the ranking.

Differences in microbial digestion among the species studied were mainly based on the rate at which the cell contents and the pectin of the cell walls were fermented, since differences diminished with the time of incubation, and became not significant after $48 \mathrm{~h}$ of incubation (Figure 1). In this way, $A$. vulneraria and $G$. verum, with a higher proportion of cell contents, were the most fermentable species. In addition, the cell walls of legumes and other dicotyledenous species are rich in pectin, which are rapidly degraded by the rumen microbes (Hatfield and Weimer, 1995). In agreement with the low fermentation rates of grasses and E. horridum in the present study, López et al. (1991b) observed that among the species from a meadow at $1150 \mathrm{~m}$ above sea level, grasses have a slower rumen fractional degradation rate than legumes and other species. A higher rumen degradation rate of legumes compared with grasses has already been reported (Beever et al., 1986; Grenet, 1989).

Despite the stage of maturity being more advanced for the legume (A. vulneraria) on nearly all collection dates, it produced a higher volume of gas than the herbaceous dicotyledenous variety $G$. verum for the first $8 \mathrm{~h}$ of incubation (Figure 1). Furthermore, the $\mathrm{N}$ content of $A$. vulneraria was not affected to a great extent by date, being reduced by a factor of only 0.06 from June to September. In contrast, that of G. verum was reduced by a factor of 0.41 in the same period. It is worth noting the reduction of the cell wall proportion, and the increase in enzymatic digestion in A. vulneraria as the summer advances, with no 
apparent changes in gas production. This apparent contradiction has been observed previously in this species (García-González and Alvera, 1986) and also in other dicotyledenous species (Hanley and McKendrik, 1983). The high digestibility of $A$. vulneraria which remained constant throughout the vegetative period suggests that this species is potentially a good forage resource for animal production in poor soils (Often, 1998) or in mountain production systems. Among the other species, there were no major differences in microbial fermentation, as might have been expected from their NDF and ADF content.

In the current study, the date of sampling did not affect chemical composition, except for $\mathrm{N}$ proportion, nor gas production until $24 \mathrm{~h}$ incubation. The regrowth observed in some samples of $G$. verum and E. horridum in September seems not to have affected their chemical composition to a great extent. López et al. (1991a) even reported higher fibre contents and lower digestibility in mountain meadows harvested in June compared to subsequent cuts, probably because of a lower leaf to stem ratio. However, in our case from $24 \mathrm{~h}$ onwards there was a linear negative effect of the sampling date on gas production. Although the extent of lignification has been considered to be one of the main parameters affecting forage digestibility (Jung and Deetz, 1993), no significant correlation was observed with gas production at 12, 24 or $48 \mathrm{~h}$ (Table 5). Therefore, the effect of date on fermentation must be explained by differences in the anatomical structure of forages. In this sense, physical structures may form a barrier that prevents microbial action on potentially fermentable tissues in samples from August and September compared with June and July (Figure 2). In agreement with this hypothesis, the lignification of plants as maturity advances is not the only factor affecting microbial fermentation, but more importantly its location in specific tissues must be implicated (Wilson and Hatfield, 1997), especially with long fermentation periods. This may also explain why in vitro enzymatic digestibility agrees better with gas production results than chemical composition estimates with gas production results (Aiple et al., 1996), and therefore both the former methods seem more accurate than chemical analyses for evaluating forages at different stages of maturity.

\section{References}

Afifi, A. A. and Clark, V. 1996. Computer-aided multivariate analysis. Lifetime Learing Publications, Belmont, California.

Aiple, K. P., Steingass, H. and Drochner, W. 1996. Prediction of the net energy content of raw materials and compound feeds for ruminants by different laboratory methods. Archives of Animal Nutrition 49: 213-220.
Aldezábal, A. 2001. El sistema de pastoreo del Parque Nacional de Ordesa y Monte Perdido (Pirineo Central, Aragón). Interacción entre la vegetación supraforestal y los grandes herbívoros. Consejo de Protección de la Naturaleza de Aragón, Zaragoza, Spain.

Association of Official Analytical Chemists. 1990. Official methods of analysis, 15th edition. Arlington, VA.

Aufrère, J. and Michalet-Doreau, B. 1988. Comparison of methods for predicting digestibility of feeds. Animal Feed Science and Technology 20: 203-218.

Beever, D. E., Dhanoa, M. S., Losada, H. R., Evans, R. T., Cammell, S. B. and France, J. 1986. The effect of forage species and stage of harvest on the processes of digestion occurring in the rumen of cattle. British Journal of Nutrition 56: 439-454.

Braun-Blanquet, J. 1948. La Végétation Alpine des Pyrénées Orientales. Monografía de la Estación de Estudios Pirenaicos y del Instituto Español de Edafología, Ecología y Fisiología Vegetal, Barcelona, Spain.

France, J., Dhanoa, M. S., Theodorou, M. K., Lister, S. J., Davies, D. R. and Isac, D. 1993. A model to interpret gas accumulation profiles associated with in vitro degradation of ruminant feeds. Journal of Theoretical Biology 163: 99-111.

García-González, R. and Alvera, B. 1986. Relaciones entre la composición mineral de plantas abundantes en pastos supraforestales pirenaicos y su utilización por los rumiantes. XXVI Reunión Científíca de la SEEP, Consejería de Agricultura y Pesca, Oviedo, Spain, pp. 249-265.

García-González, R., Gómez, D. and Remón, J. L. 1991. Application of vegetation maps to the study of grazing utilization: a case in the Western Pyrenees. Phytocoenology 3: 251-256.

García-González, R., Hidalgo, R. and Montserrat, C. 1990. Patterns of time and space use by livestock in the Pyrenean summer ranges: a case study in the Aragon valley. Mountain Research and Development 10: 241-255.

Gómez, D., Castro, O. and Aldezábal, A. 1997. Species richness, biomass and plant production in subalpine plant communities in the Spanish Pyrenees. Proceedings of the $36^{\text {th }}$ IAVS symposium, Universidad de La Laguna, Tenerife, Spain, pp. 101-112.

González Ronquillo, M., Fondevila, M., Barrios Urdaneta, A. and Newman, Y. 1998. In vitro gas production from buffel grass (Cenchrus ciliaris L. ) fermentation in relation to the cutting interval, the level of nitrogen fertilisation and the season of growth. Animal Feed Science and Technology 72: 19-32.

Grenet, E. 1989. A comparison of the digestion and reduction in particle size of lucerne hay (Medicago sativa) and Italian ryegrass hay (Lolium italicum) in the ovine digestive tract. British Journal of Nutrition 62: 493-507.

Hanley, T. A. and McKendrick, J. D. 1983. Seasonal changes in chemical composition and nutritive value of native forages in a spruce-hemlock forest, southeastern Alaska. Pacific Northwest Forest and Range Experiment Station Forest Service, Department of Agriculture, Alaska.

Hatfield, R. D. and Weimer, P. J. 1995. Degradation characteristics of isolated and in situ cell wall lucerne pectic polysaccharides by mixed ruminal microbes. Journal of the Science of Food and Agriculture 69: 185-196. 
Jung, H. G. and Deetz, D. A. 1993. Cell wall lignification and degradability. In Forage cell wall structure and digestibility (ed. H. G. Jung, D. R. Buxton, R. D. Hatfield and J. Ralph), pp. 315-346. ASA-CSSA-SSSA, Madison.

Khazaal, K., Dentinho, M. T., Ribeiro, J. M. and Ørskov, E. R. 1995. Prediction of apparent digestibility and voluntary intake of hays fed to sheep: comparison between using fibre components, in vitro digestibility or characteristics of gas production or nylon bag degradation. Animal Science 61: 527-538.

López, S., Carro, M. D., González, J. S. and Ovejero, F. J. 1991a. The effect of method of forage conservation and harvest season on the rumen degradation of forages harvested from permanent mountain meadows. Animal Production 53: 177-182

López, S., Carro, M. D., González, J. S. and Ovejero, F. J. 1991b. Rumen degradation of the main forage species harvested from permanent mountain meadows in NorthWestern Spain. Journal of Agricultural Science, Cambridge 117: 363-369.

Menke, K. H. and Steingass, H. 1988. Estimation of the energetic feed value obtained from chemical analysis and in vitro gas production using rumen fluid. Animal Research and Development 28: 7-55.

Minson, D. J. 1998. A history of in vitro techniques. In In vitro techniques for measuring nutrient supply to ruminants (ed. E. R. Deaville, E. Owen, A. T. Adesogan, C. Rymer, J. A. Huntington and T. L. J. Lawrence), British Society of Animal Science occasional publication no. 22, pp. 13-19.

Montserrat, P. and Fillat, F. 1990. The systems of grassland management in Spain. In Managed grasslands (ed. A. Breymeyer), pp. 37-70. Elsevier, Amsterdam.
Often, A. 1998. The use of Anthyllis vulneraria s.1. in artificial meadows in Norway, with some additional data on other "old" fodder plants. Blyttia 56: 208-219.

StatSoft. 1995. Statistica for Windows. Microsoft, Tulsa, OK.

Theodorou, K. M., Williams, B. A., Dhanoa, M. S., McAllan, A. B. and France, J. 1994. A simple gas production method using a pressure transducter to determine the fermentation kinetics of ruminant feeds. Animal Feed Science Technology 48: 185-197.

Ugherughe, P. O. 1986. Relationship between digestibility of Bromus inermis and plant parts. Journal of Agronomy and Crop Science 157: 136-143.

Van Soest, P. J. 1994. Nutritional ecology of the ruminant. Cornell University Press, New York.

Van Soest, P. J., Robertson, J. B. and Lewis, B. A. 1991. Methods for dietary fibre, neutral detergent fibre and nonstarch polysaccharides in relation to animal nutrition. Journal of Dairy Science 74: 3583-3597.

Weiss, B. P. 1995. Estimation of digestibility of forages by laboratory methods. In Forage quality, evaluation and utilization (ed. G. C. Fahey, M. Collins, D. R. Mertens and L. E. Moser), pp. 644-681. ASA-CSSA-SSSA, Madison, USA.

Wilson, J. R. and Hatfield, R. D. 1997. Structural and chemical changes of cell wall types during stem development: consequences for fibre degradation by rumen microflora. Australian Journal of Agricultural Research 48: 165-180.

(Received 15 June 2002-Accepted 5 December 2002) 